The Lichenologist 41(5): 453-456 (2009) (C) 2009 British Lichen Society doi:10.1017/S0024282909990181 Printed in the United Kingdom

\title{
Editorial
}

\section{Professor Ingvar Kärnefelt - a birthday tribute}

On 19 July 2009 Ingvar Kärnefelt celebrated his 65 th birthday. This could have meant that we, his former students, would be celebrating him in his retirement from his position as head of the Biological Museums at Lund University. We are grateful that this is not the case, as Ingvar will carry on, probably for at least one or two more years. Instead, we celebrate Ingvar because he is the main reason for all of us having studied lichenology in Lund. This special issue of The Lichenologist is dedicated to him as a birthday tribute in honour of his long and fruitful lichenological career. The main authors of all the papers in this issue are former students of Ingvar. For several of us he has not only acted as supervisor but later also as the director of the Botanical Museum where we meet him in our daily work.

Jan Eric Ingvar Kärnefelt was born in Gothenburg, Sweden in 1944. He began his higher level studies at the University of Cologne 1966-1967 to become a dentist; however, he turned to biology and the University of Gothenburg in 1968. There he, like many others, was inspired by Gunnar Degelius who was his first teacher during undergraduate studies in botany in 1968 . When Degelius retired in 1969 Ingvar moved to Lund University to continue his studies as Hans Runemark held a position in systematic botany there. In 1971 he met Ove Almborn, who became his supervisor and one year later he began to work on his thesis "The brown fruticose species of Cetraria" that he defended in 1979. The thesis was later awarded a prize for the best doctoral dissertation in botany at Lund University during a 5-year period by the Royal Physiographic Society in Lund. His Ph.D. thesis was followed by a

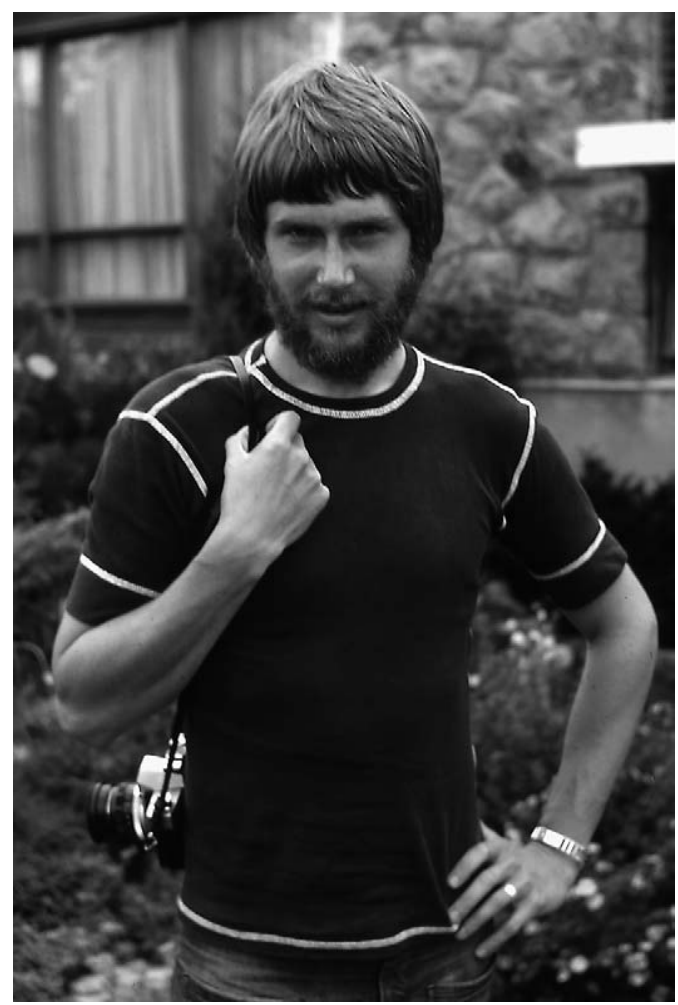

Ingvar as a young Ph.D. student in Ottawa. Photo by I. Brodo.

taxonomic study on "Bryocaulon, Coelocaulon and Cornicularia and formerly associated taxa". These works represent milestones in the taxonomy of the family Parmeliaceae. Over the years Ingvar has kept up his interest in the family and has published numerous works on species and generic delimitations of the various groups within the family. Presently we look forward to a new volume of the 


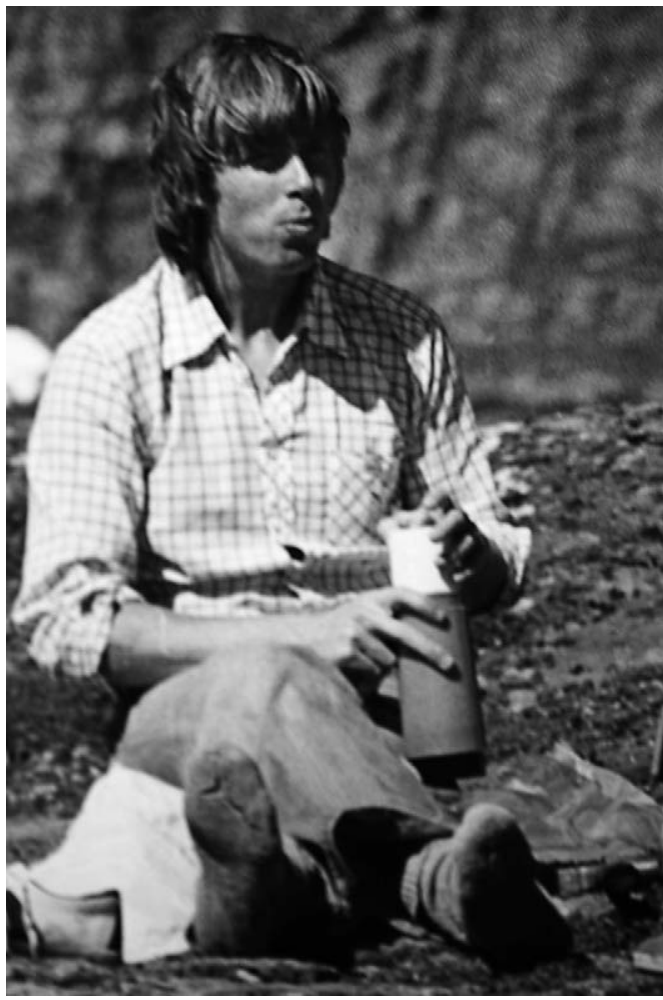

Ingvar in the field in Jämtland in northern Sweden in 1975. Photo by U. Søchting.

Nordic Lichen Flora where he is one of the authors treating the species of Parmeliaceae.

Ingvar also became interested in the taxonomy and evolution of another family, the Teloschistaceae. In 1987 he described Caloplaca almbornii from southern Africa and this paper has been followed by many other contributions dealing with this family. $\mathrm{He}$ is certainly still very active in this field, currently in a series of publications dealing with the Teloschistaceae flora of Australia.

In 1986 Ingvar secured a position as associate professor at the Department of Systematic Botany and as a result lichenology in Lund expanded enormously. Apart from his very first student, the following eight Ph.D. students (listed in following paper) have carried out studies in lichen systematics. As a supervisor Ingvar is patient, encouraging and has always given us plenty of free space to formulate our Ph.D. projects. However,

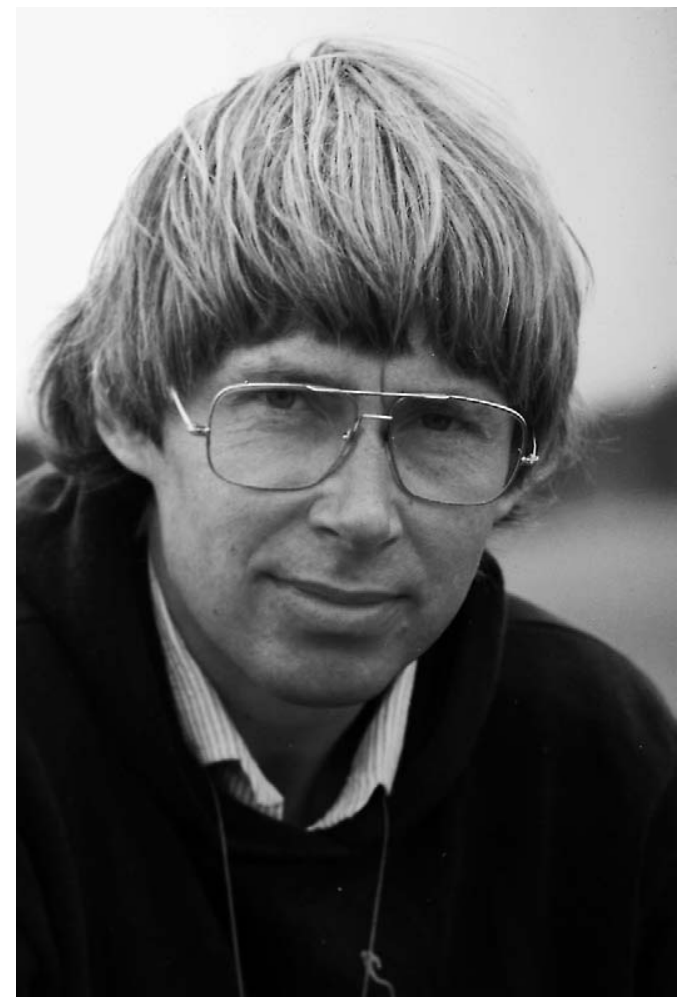

Ingvar on the island of Öland in 1984. Photo by U. Søchting.

through his career many innovations have appeared in the field of taxonomy and he always eagerly encouraged us to learn and try out the latest methods, for example, thinlayer chromatography, the use of ascus characters in taxonomy, cladistics and molecular methods.

As a supervisor he made great efforts to introduce us into the world of lichenologists. $\mathrm{He}$ always communicated to us the latest personal and professional information that he received from colleagues from all around the world. Consequently, we almost immediately became members of a large global family of lichenologists that has kept us in touch both at a professional and private level. Furthermore, he always urged us to participate in scientific meetings and excursions, and also to visit colleagues in different parts of the world who could make us better prepared to fulfil our scientific education. He would 


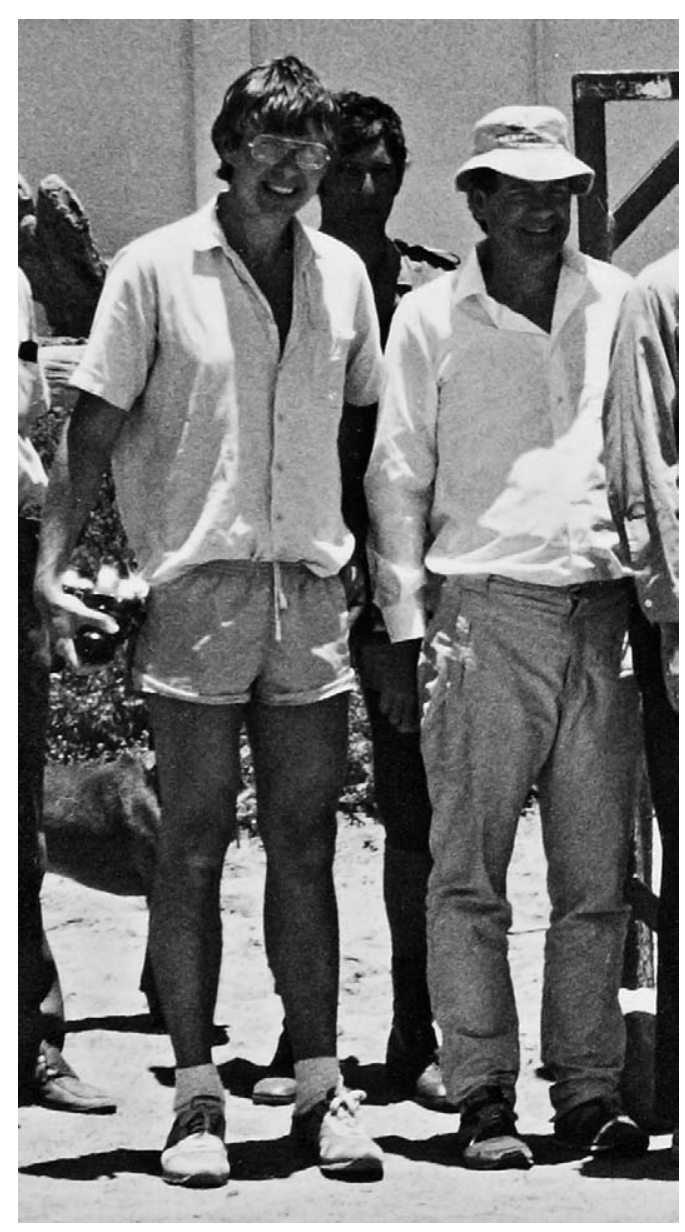

Ingvar in Namibia 1986, with Tom Nash on his left.

claim: "Within three months a Ph.D. student has better knowledge in his own field than the supervisor." This demonstrates his awareness of the importance of collective supervision involving many colleagues with different skills.

In the late $1980 \mathrm{~s}$ the importance of cryptogams became recognized in nature conservation and they were increasingly used for assessing conservation values. Ingvar was influenced by this progress and in 1987 he successfully applied for a grant for a project concerning the status and development of threatened lichens in southern Sweden. This project started rather modestly, but during the following years it grew and became one of the most important external projects at the department. For several years this project supported his Ph.D. students financially by providing a source of income during the initial period of a Ph.D. project, which was often rather harsh in those days. The project ran until 1995 and finally resulted in a much cited book in 1997, presenting the results of many years of field work and extensive data analyses.

In 1994 Ingvar became the Director of the Botanical Museum and in 2000 he was appointed Professor. In 2002, when there were large reorganizations at Lund University his directorship was extended to include also the Zoological Museum, which together with the Botanical Museum, now form a separate department called the Biological Museums. During this period of reorganization, the curatorial activities as well as research in systematics at the Biological Museums were seriously threatened. However, Ingvar has played a key role in several successful applications for large grants, which were made available by the Swedish Species Information Centre. The purpose of these grants is to support Swedish biological museums in the work to digitize and curate their collections. These have resulted in extended activity and the employment of several persons, including former students, during recent years, which have made the museums more influential at the university.

Ingvar has always been a very social member of the global lichenological family and he has many friends around the world. His international commitments include organizing the IAL2 symposium in Hemmeslöv, Sweden in 1992. Between 1992 and 1996 he served as the President of the IAL and during IAL3 in Salzburg 1996, Ingvar was elected Honorary President of the IAL for life. He was also Editor-in-chief for the journal of the Nordic Lichen Society, Graphis Scripta, between 1997 and 2005 and he has served on the Editorial Board for Nordic fournal of Botany since 2001, as well as co-edited several volumes of Bibliotheca Lichenologica. Ingvar is immensely fond of travelling and his interest in lichenology has taken him to 


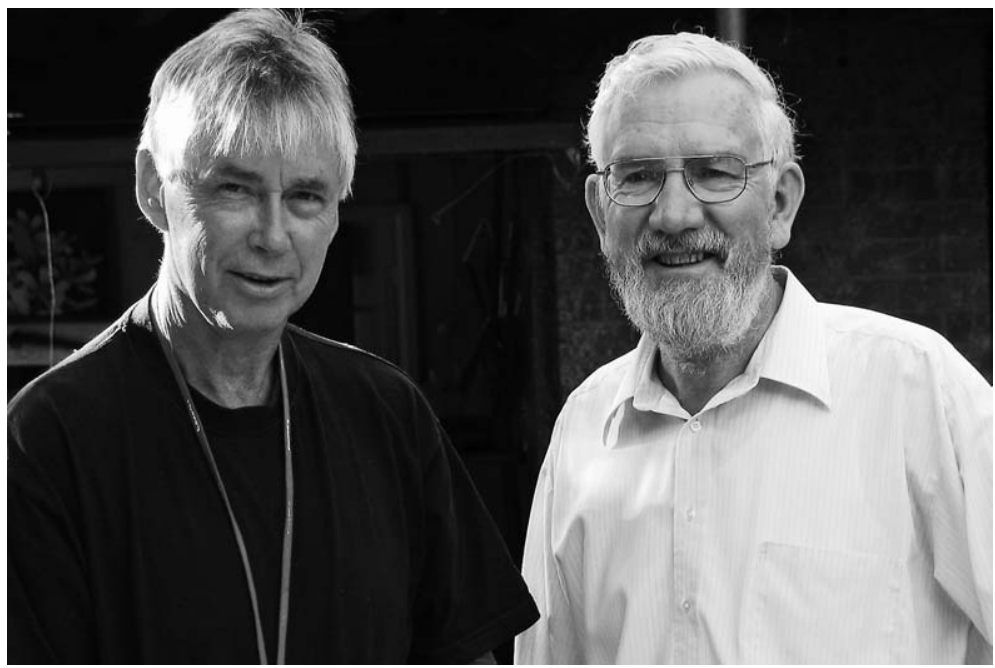

Ingvar visiting Jack Elix in Australia in 2004.

places in most continents both as a guest researcher and on excursions resulting in important herbarium collections. The list of many exotic places now represented in LD includes New Zealand, Tasmania, South Georgia, Namibia, eastern Russia and Arctic Canada to name but a few. Among his destinations we also have to mention Austria, where Ingvar, every summer for the past 15 years, has spent a few weeks in the lovely surroundings of Bad Gastein. Here he shares his knowledge of botany during daily walks in the Alps with crowds of eager-to-learn tourists and amateur botanists. They not only receive a wealth of botanical wisdom but also historical tales and anecdotes about kings and queens of the European 19th and 20th centuries. Ingvar has, like many other botanists, a great historical interest and this has generated several articles about, for example, the IAL and about famous scientists such as Welwitsch, Darwin, and Acharius.

Ingvar is a versatile man and through the years we have met him in his various roles as teacher, supervisor, boss, colleague, coworker and friend. We have all enjoyed and benefited from his knowledge, experience, and his vast network of contacts, his patience and sense of humour. Without the support from Ingvar over the years the lichenological group that was established in Lund 25 years ago would probably never have been formed or would have ceased to exist long ago. For a number of years it was the largest lichenological research group that has ever existed in Sweden. His acceptance of our different personalities and interests from the beginning of our careers until today is an essential explanation of the diversity of lichenology presented in this issue.

The Senior Editor of The Lichenologist generously agreed to provide us the space needed for the lichenological contributions authored by us. All papers are dedicated to Ingvar, in honour of his importance to lichenology in general and lichenology in Lund in particular. Finally, we would like to express our sincere gratitude to Ingvar, our Doktorvater, and wish him all the best in his future work and good health for many years to come.

Ulf Arup (acting co-editor), Stefan Ekman, Lars Fröberg, Patrik Frödén, Tommy Knutsson, Håkan Lättman, Louise Lindblom, Jan-Eric Mattsson, Arne Thell and Martin Westberg 